University of Nebraska - Lincoln

DigitalCommons@University of Nebraska - Lincoln

Biological Systems Engineering: Papers and

Publications

Biological Systems Engineering

2003

\title{
Molecular Dynamics of Soy-Protein Isolate Films Plasticized by Water and Glycerol
}

\author{
S.-G. Choi \\ University of Georgia, Athens, \\ K. M. Kim \\ Milford Hanna \\ University of Nebraska-Lincoln, mhanna1@unl.edu \\ Curtis L. Weller \\ University of Nebraska-Lincoln, cweller1@unl.edu \\ W. L. Kerr \\ University of Georgia, Athens, wlkerr@arches.uga.edu
}

Follow this and additional works at: https://digitalcommons.unl.edu/biosysengfacpub

Part of the Biological Engineering Commons

Choi, S.-G.; Kim, K. M.; Hanna, Milford; Weller, Curtis L.; and Kerr, W. L., "Molecular Dynamics of Soy-Protein Isolate Films Plasticized by Water and Glycerol" (2003). Biological Systems Engineering: Papers and Publications. 185.

https://digitalcommons.unl.edu/biosysengfacpub/185

This Article is brought to you for free and open access by the Biological Systems Engineering at DigitalCommons@University of Nebraska - Lincoln. It has been accepted for inclusion in Biological Systems Engineering: Papers and Publications by an authorized administrator of DigitalCommons@University of Nebraska Lincoln. 
Published in Journal of Food Science: Food Engineering and Physical Properties 68:8 (2003), pp. 2516-2522.

Copyright (c) 2003 Institute of Food Technologists. Used by permission.

Submitted April 8, 2003; revised June 16, 2003; accepted August 14, 2003.

\title{
Molecular Dynamics of Soy-Protein Isolate Films Plasticized by Water and Glycerol
}

\author{
S.-G. Choi, ${ }^{1}$ K. M. Kim, ${ }^{2}$ M. A. Hanna, ${ }^{2}$ C. L. Weller, ${ }^{2}$ and W. L. Kerr ${ }^{1}$ \\ 1. Department of Food Science Technology, University of Georgia, Athens, GA 30602 \\ 2. University of Nebraska-Lincoln, Lincoln, NE. \\ Corresponding author - W. L. Kerr, email wlkerr@arches.uga.edu
}

\begin{abstract}
The effects of water and glycerol on the molecular mobility of a soy-protein isolate (SPI)-based film were investigated using ${ }^{1} \mathrm{H}$ nuclear magnetic resonance (NMR). SPI-films were prepared with different glycerol contents and equilibrated to various levels of water activity $\left(\mathrm{a}_{\mathrm{w}}\right)$. The distributed transverse relaxation of film samples showed 2 distinct components: a solid-like fraction $\left(\mathrm{T}_{2 \mathrm{~s}}{ }^{*}\right)$ and a liquid-like fraction $\left(\mathrm{T}_{2 \mathrm{~m}}{ }^{*}\right)$. The peak $\mathrm{T}_{2 s}{ }^{*}$ values of films with lower glycerol concentration were more sensitive to variation in aw. As $\mathrm{a}_{\mathrm{w}}$ increased, the change of solidlike to liquid-like fraction was observed in higher glycerol films. As glycerol content increased, a minimum longitudinal relaxation time ( $\left.\mathrm{T}_{1}\right)$ occurred at lower $\mathrm{a}_{\mathrm{w}}$. Our results suggest that NMR techniques can be used to quantify the plasticizing effects on biopolymer films.
\end{abstract}

Keywords: molecular mobility, NMR, edible film, glycerol, water

\section{Introduction}

Edible films can improve food quality and increase food product shelf-life by serving as selective barriers to moisture transfer, oxygen uptake, loss of volatile flavors and aromas, and lipid oxidation (Kester and Fennema 1986). Considerable research has been reported on the preparation and evaluation of hydrocolloid-based films made from proteins and polysaccharides (Gontard and Guilbert 1994; Krochta and others 1994; Cuq and others 1995; Stading and Hermansson 2000; Monahan and others 2002; Barbot and others 2003). Edible films generally consist of at least 2 major components: a high-molecular-weight film-forming polymer and a plasticizer. A plasticizer is a small molecule with low volatility and a chemical nature similar to that of the film-forming polymer. Generally, plasticizers are used in films to increase film flexibility and processibility. The most commonly used plasticizers for protein-based films are glycerol, glycols, and other hydroxyl compounds (Banker 1966). Stuchell and Krochta (1994) showed that soy protein films could be handled only if at least $17 \mathrm{~g}$ glycerol/100 g dry matter were included in the formulation. The addition of plasticizer also induces changes in moisture sorption, mechanical properties, and water and oxygen barrier properties of the film, depending on the level and type of plasticizer (McHugh and Krochta 1994; Park and others 1994; Cherian and others 1995). The addition of plasticizers results in a decrease in the glass transition temperature of edible films (Cherian and others 1995; Gontard and Ring 1996).

Physical and barrier properties of hydrophilic protein films are also influenced by the water concentration in the film (Gennadios and others 1993; Gontard and others 1993). Protein-based films tend to absorb large quantities of water, depending on relative humidity (RH). Water has been considered to be the "natural or ubiquitous" plasticizer of most hydrocolloid-based films, and water has been shown to affect the functional properties of protein-based films by plasticization, swelling, or solubilization (Gontard and others 1993; Morillon and others 2000). Gontard and others (1993) showed that mechanical properties and water vapor properties of gluten films were affected by moisture content. Cho and Rhee (2002) found that the effect of RH on mechanical properties of soy protein isolate (SPI) films varied with the type and concentration of plasticizers.

The mechanical and rheological properties of foods and biological materials depend on the molecular dynamics of polymers, water, and other constituents. Nuclear magnetic resonance (NMR) is a powerful technique for determining molecular dynamics and physical structure of foods and biological materials through the analysis of spin magnetization relaxation. Relaxation of spins occurs due to the interactions between individual spins and between a spin and its environment. Whereas the signal intensity in an NMR experiment is proportional to the number of nuclei present, the decay of spin magnetization is related to the mobility of such nuclei. The relaxation behavior is commonly characterized by the transverse relaxation time $\left(\mathrm{T}_{2}\right)$ and longitudinal relaxation time $\left(\mathrm{T}_{1}\right)$. Kou and others (2000), investigating the mobility of waxy cornstarch using wide-line ${ }^{1} \mathrm{H}$ NMR, reported that proton relaxation times (that is, $\mathrm{T}_{2}{ }^{*}, \mathrm{~T}_{2}$, and $\mathrm{T}_{1}$ ) can be indicators of glass transitions in starch samples. Using pulsed ${ }^{1} \mathrm{H}$ NMR techniques, Choi and Kerr (2003) identified and quantified the molecular mobility of both starch and water molecules in starchwater suspensions at low moisture level and at different $a_{w}$ levels.

The goals of this research were to investigate the effects of various combinations of water and glycerol on the molecular mobility of SPI-based edible films, and to study the interactions between the water and glycerol molecules in the films. This will help to more accurately characterize the roles of glycerol and water in the formulation of protein-based edible films and to better understand changes in functional properties of the films under different relative humidity conditions.

\section{Materials and Methods}

\section{Preparation of SPI film}

Film-forming solutions were prepared by mixing $100 \mathrm{~mL}$ distilled water, 5g SPI (Supro 620, Protein Technologies Intl., 
St. Louis, Mo., U.S.A.), and 1.5, 2.5, and $3.5 \mathrm{~g}$ of glycerol (USP grade, Mallinckordt, Paris, Ky., U.S.A.). Sodium hydroxide $(1 \mathrm{~N})$ was used to adjust the $\mathrm{pH}$ of the film-forming solutions to $10.00 \pm 0.01$. The solutions were held for $15 \mathrm{~min}$ in a water bath at $75{ }^{\circ} \mathrm{C}$ and then strained through cheesecloth (Cheesecloth wipes ${ }^{\mathrm{TM}}$, VWR Scientific Products, Chicago, Ill., U.S.A.) to remove any bubbles and lumps. Film-forming solutions ( 90 $\mathrm{mL})$ were cast on flat, level Teflon ${ }^{\circledR}$-coated glass plates $(21 \mathrm{~cm}$ $\times 35 \mathrm{~cm}$ ). Films were peeled from the plates after drying at ambient temperature for $20 \mathrm{~h}$.

\section{Moisture sorption isotherm}

Soy protein film specimens were conditioned in desiccators for $3 \mathrm{~d}$ at $11 \% \mathrm{RH}$ to reduce the initial moisture content. Triplicate predried samples (approximately $0.7 \mathrm{~g}$ each) were put into 6.3-cm hexagonal polystyrene weighing dishes (Fisher Scientific Co., Pittsburgh, Pa., U.S.A.) and further dehydrated in a desiccator over $\mathrm{P}_{2} \mathrm{O}_{5}$ for 7 to $10 \mathrm{~d}$, until no further weight loss was observed. Samples were then assumed to be at $0 \%$ moisture content (dry basis).

The dehydrated samples were equilibrated in desiccators containing various saturated salt solutions of known relative vapor pressures ranging from 0 to 0.93 at $25^{\circ} \mathrm{C} ; \mathrm{P}_{2} \mathrm{O}_{5}$, approximately 0; $\mathrm{LiCl}, 0.11 ; \mathrm{KCH}_{3} \mathrm{CO}_{2}, 0.23 ; \mathrm{MgCl}_{2}, 0.33 ; \mathrm{K}_{2} \mathrm{CO}_{3}$, 0.43; $\mathrm{Mg}\left(\mathrm{NO}_{3}\right)_{2}, 0.53$; $\mathrm{KI}, 0.69$; $\left(\mathrm{NH}_{4}\right)_{2} \mathrm{SO}_{4}, 0.81$; and $\mathrm{KNO}_{3}$, 0.93. Equilibrium was assumed when there was no further change in weight between consecutive daily weighing. Equilibrium moisture content $(\% \mathrm{db})$ was calculated from the gain in weight.

\section{NMR measurements}

Proton relaxation measurements were made using a 20 $\mathrm{MHz}{ }^{1} \mathrm{H}$ NMR spectrometer (Resonance Instruments, Whitney, U.K.). Approximately $0.5-\mathrm{g}$ samples were removed from the desiccators and placed into glass vials $(50-\mathrm{mm}$ height $\times 10$ $\mathrm{mm}$ diameter) and then immediately returned to the desiccators. After an additional 24-h equilibration period, the vials with samples were placed in 18-mm diameter NMR tubes and then covered with parafilm.

Transverse relaxation $\left(\mathrm{T}_{2}\right)$ curves were developed using both single-pulse and Carr-Purcel-Meiboom-Gill (CPMG) pulse sequences (Meiboom and Gill 1958). Acquisition parameters were set to a $90^{\circ}$ pulse of $4.1 \mu$ s and a recycle delay of 2 $\mathrm{s}$. The $90^{\circ}$ to $180^{\circ}$ pulse spacing ( $\tau$ ) was set to $60 \mu \mathrm{s}$. All measurements were made at $25 \pm 0.1^{\circ} \mathrm{C}$. Relaxation curves obtained from both the single-pulse and CPMG sequences were analyzed using a distributed exponential routine (Win DXP, Resonance Instruments). Based on the "contin" algorithm of Provencher (1982), this routine calculates a distribution of $\mathrm{T}_{2}$ terms that best describe the data:

$$
g_{i}=\sum_{j=1}^{m} f_{j} e^{-t / T_{2, j}}
$$

where $g_{i}$ are the values of the exponential distribution at time $t_{i}, f_{j}$ are the pre-exponential multipliers, and $T_{2, j}$ are the time constants. In general, the distributions assumed more than one distributed region, suggesting the existence of various regions of water with similar mobility. In this case, the number of protons in a given region was measured by the integrated signal intensity over the region of the distribution.

Longitudinal relaxation $\left(\mathrm{T}_{1}\right)$ experiments were accomplished using an inversion recovery sequence, with $\tau$ varying logarithmically from 1 to 2000 ms over 30 steps. The obtained curves were analyzed by fitting the data to a mono-exponential decay function.

\section{Statistical analysis}

The data were analyzed using the SAS program (SAS Institute, Inc., Cary, N.C., U.S.A.). Analysis of variance was used to determine the significance of variable effects on water sorption properties and proton relaxation behavior. The level of significance was defined as $P<0.05$.

\section{Results and Discussion}

\section{Sorption isotherms for SPI films with different levels of glycerol}

Moisture adsorption data of SPI films prepared with different levels of glycerol at $25{ }^{\circ} \mathrm{C}$ were fitted to a Guggenheim-Anderson-de Boer [GAB] model (Figure 1). The sorption curves of SPI films were typical of polymer films such as those made from cellulose or proteins (De Leiris 1985; Mahmoud and Savello 1992; Gontard and others 1993; Cho and Rhee 2002). The equilibrium moisture content increased with $\mathrm{a}_{\mathrm{w}}$ and showed significant differences among samples at $\mathrm{a}_{\mathrm{w}}>$ 0.33. Films with a higher concentration of glycerol absorbed more moisture at $\mathrm{a}_{\mathrm{w}}>0.33$, which is consistent with results found for other edible films (Mahmoud and Savello 1992; Gennadios and Weller 1994; Cho and Rhee 2002). The greater water sorptive capacity in films with more glycerol may be attributed to the hydrophilicity of glycerol molecules. In addition, it may be due to structural modifications of protein network by glycerol. The sorption data for all samples were well fit to a GAB model $\left(r^{2}>0.98\right)$. The GAB constant $(C)$ decreased with increased glycerol, 3.733, 2.996, and 2.679 for $0.3,0.5$, and $0.7 \mathrm{~g}$ glycerol/g SPI, respectively. The fitting of sorption data by the GAB model showed that monolayer values were influenced by glycerol content. The monolayer values of SPI film were $0.060,0.072$, and $0.080 \mathrm{~g} \mathrm{H}_{2} \mathrm{O} / \mathrm{g}$ solid for films with $0.3 \mathrm{~g}, 0.5$ $\mathrm{g}$, and $0.7 \mathrm{~g}$ glycerol/g SPI, respectively. Cho and Rhee (2002) reported values of $0.068 \mathrm{~g}$ to $0.096 \mathrm{~g} \mathrm{H}_{2} \mathrm{O} / \mathrm{g}$ solid for SPI films prepared with glycerol.

\section{Transverse relaxation from single-pulse experiment}

Single-pulse transverse relaxation data for SPI films was analyzed using a distributed exponential model. In general, data were well fit with a distributed exponential model; standard errors were 0.01 or less. This technique distinguishes protons in solid-like components from those in liquid-like regions. Protons in solid-like components are characterized by short relaxation times, whereas those in more mobile regions have longer relaxation times.

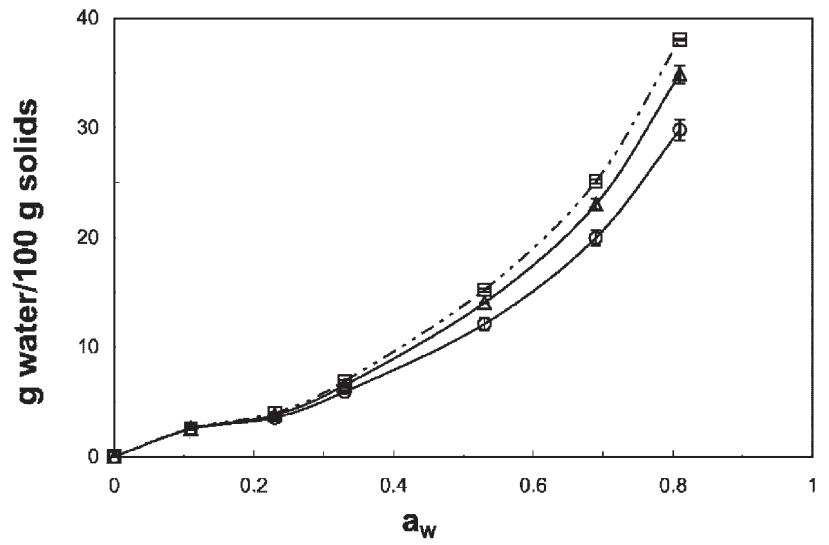

Figure 1. Moisture sorption isotherms for soy-protein isolate (SPI) films with different glycerol contents. $\circ=0.3 \mathrm{~g}$ glycerol $/ \mathrm{g}$ SPI; $\Delta=$ $0.5 \mathrm{~g}$ glycerol $/ \mathrm{g}$ SPI; $\square=0.7 \mathrm{~g}$ glycerol $/ \mathrm{g}$ SPI. 
Effect of glycerol concentration at $\mathbf{a}_{\mathrm{w}}$ of approximately $\mathbf{0}$. Distributed relaxation curves for SPI films with different glycerol concentration at $\mathrm{a}_{\mathrm{w}}$ of approximately 0 are shown in Figure 2. For the films with $0.7 \mathrm{~g}$ of glycerol/g SPI, the distributed relaxation showed 2 distinct components. The solid-like component had a maximum time constant $\left(\mathrm{T}_{2 \mathrm{~s}}{ }^{*}\right)$ in the range of 8.8 to $10.0 \mu \mathrm{s}$, whereas the liquid- like component had a maximum time constant $\left(\mathrm{T}_{2 \mathrm{~m}}{ }^{*}\right)$ in the range of 140 to $180 \mu \mathrm{s}$. However, for the films with $0.3 \mathrm{~g}$ and $0.5 \mathrm{~g}$ of glycerol/g SPI, only 1 solid-like component was observed. Because all the solid protons relax very rapidly, within tens of microseconds, the long time constant $\left(\mathrm{T}_{2 \mathrm{~m}}{ }^{*}\right)$ is likely from relatively mobile glycerol molecules. The glycerol concentration in the film formulation affected the peak $\mathrm{T}_{2 \mathrm{~s}}{ }^{*}$ of film at $\mathrm{a}_{\mathrm{w}}$ of approximately 0 . The peak $\mathrm{T}_{2 \mathrm{~s}}{ }^{*}$ values of films increased from 8.8 to $10.0 \mu \mathrm{s}$, with increasing concentration of glycerol in the film. This indicates that the mobility of SPI film increased due to plasticizing by glycerol molecules.

Plasticizers are often used in films to prevent brittleness by reducing intermolecular forces and increasing the mobility of polymer chains and film flexibility. Glycerol is a relatively small hydrophilic molecule, is easily incorporated between protein chains, and can establish hydrogen bonds with amide groups of SPI (Banker 1966). Our results suggest that NMR techniques can be used to quantify the plasticizing effects on biopolymer films, because it is a measure of biopolymer and solvent mobility. The type of dynamics measured, however, is of a specific nature. NMR relaxation rates, including $R_{1}=1 / T_{1}$ and $R_{2}=1 / T_{2}$, are related to linear combinations of the spectral density functions $J^{(0)}(\omega), J^{(1)}(\omega)$, and $J^{(2)}(\omega)$, which take the form:

$$
J^{(i)}(\omega)=\frac{k_{i} \tau_{c}}{r_{i j}^{6}\left(1+\omega \tau_{c}\right)}
$$

where $k_{i}$ is a constant that depends on whether $i=0,1$, or 2 . The significant term for discussion is the rotational correlation time, $\tau_{c}$. Although $\tau_{c}$ does depend on the inherent rate at which nuclear magnetic dipoles experience rotation, it also depends on the motions of other parts of the molecule to which it is attached. Relatively immobile molecules, such as those in solids, have relatively longer periods over which adjacent nuclei can interact and dephase or exchange energy with neighboring nuclei. Thus, these nuclei have relatively long correlation times and fast relaxation rates (short $\mathrm{T}_{1}$ or $\mathrm{T}_{2}$ ). Nuclei

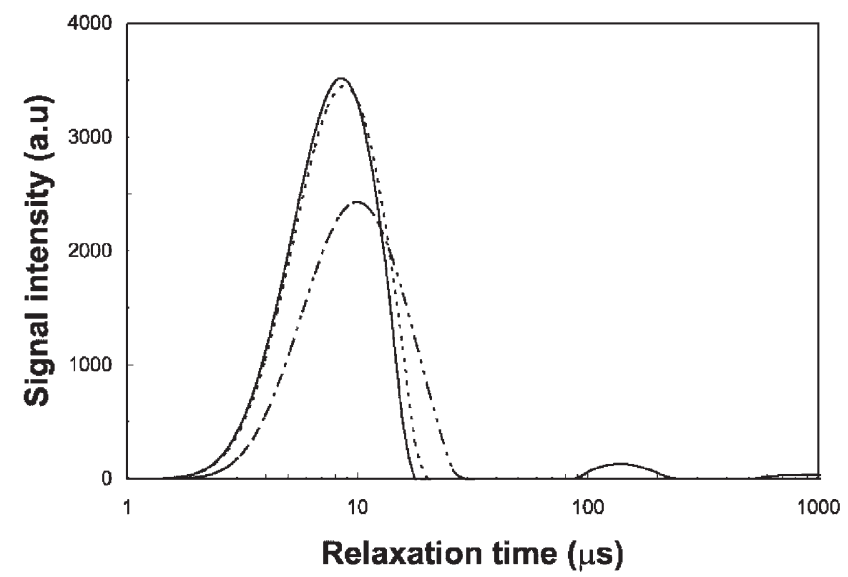

Figure 2. Distributed $T_{2}{ }^{*}$ relaxations of soy-protein isolate (SPI) films with different glycerol content at $\mathrm{a}_{\mathrm{w}}=0$, determined by single

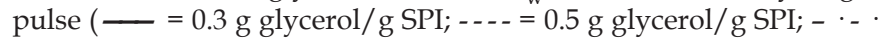
$-\cdot=0.7 \mathrm{~g}$ glycerol $/ \mathrm{g} \mathrm{SPI})$. on relatively mobile molecules have rapid motions and thus do not have long periods over which they are influenced by neighboring nuclei. These nuclei have short correlation times and slow relaxation rates (long $\mathrm{T}_{1}$ or $\mathrm{T}_{2}$ ).

It is interesting to note that when up to $0.5 \mathrm{~g}$ glycerol $/ \mathrm{g}$ SPI was incorporated, the SPI film exhibited only solid-like relaxation behavior. This suggests that glycerol mobility was coupled to protein chain mobility. This is quite different in biopolymer systems plasticized by water. Choi and Kerr (2003), investigating the molecular mobility of wheat starch-water suspensions, at moisture levels ranging from $0 \mathrm{~g}$ to 0.3 $\mathrm{g} / \mathrm{g}$ starch, found that starch chain mobility increased as water content increased, whereas water was relatively mobile compared with starch. Proton relaxations of water molecules ranged from 0.1 to $0.2 \mathrm{~ms}$ whereas those for starch chains ranged from 7 to $11 \mu \mathrm{s}$. Vittadini and others (2001) studied water mobility in a cellulose-water system over $0 \%$ to $19 \%$ water content, which was unfreezable according to differential scanning calorimetry measurements. They reported that water in those systems was highly mobile $\left(\mathrm{T}_{2}\right.$ of approximately 0.2 to $0.7 \mathrm{~ms}$ ), even though starch molecules were immobile in the glassy solid state. This suggests that water increases polymer mobility, but does not have mobility equivalent to that of polymers.

Effect of relative humidity $\left(a_{w}\right)$. The effect of $a_{w}$ on proton transverse relaxation of SPI films with different glycerol content is shown in Figures 3a-c. For films with $0.3 \mathrm{~g}$ of glycerol/g SPI, the peak $\mathrm{T}_{2 \mathrm{~s}}{ }^{*}$ values increased from 8.45 to 9.60 $\mu$ s with increasing $a_{w^{\prime}}$ indicating an increase in the mobility of solid-like component in the SPI film. In addition, a more mobile component ranging from 80 to about $100 \mu$ s was observed at $\mathrm{a}_{\mathrm{w}}=0.23$ and above (Figure $3 \mathrm{a}$ ). This more mobile fraction was observed for SPI films over all $\mathrm{a}_{\mathrm{w}}$ ranges except for $\mathrm{a}_{\mathrm{w}}=0$, indicating that it is due to relatively mobile $\mathrm{H}_{2} \mathrm{O}$ protons. For the films with glycerol of $0.5 \mathrm{~g} / \mathrm{g} \mathrm{SPI}$, peak $\mathrm{T}_{2 \mathrm{~s}}$ * values increased from 8.75 to $9.75 \mu$ s up to $\mathrm{a}_{\mathrm{w}}=0.53$. No further increase in peak $\mathrm{T}_{2 \mathrm{~s}}{ }^{*}$ was observed above $\mathrm{a}_{\mathrm{w}}=0.53$. This indicates that water plasticizes the solid-like component of the SPI films up to this $a_{w}$ level. At higher $a_{w}$, water may act as a solvent for soluble matters, resulting in decreasing solid-like component of the films. For the films with $0.7 \mathrm{~g}$ of glycerol $/ \mathrm{g}$ SPI, there were no significant changes in the peak $\mathrm{T}_{2 \mathrm{~s}}{ }^{*}$ values over all $\mathrm{a}_{\mathrm{w}}$ ranges. However, as found at other glycerol concentrations, the total signal intensity of the solid-like component decreased, whereas that of the more mobile component increased. This may indicate that solid-like component of the film with $0.7 \mathrm{~g}$ of glycerol/g SPI was not further plasticized by water and that some of the component was solubilized by water, causing an increase in material in a more mobile state.

Figures $3 \mathrm{a}$ and $3 \mathrm{~b}$ also show a second component, designated as $\mathrm{T}_{2 \mathrm{~m}}{ }^{*}$. To compensate for the effects of field inhomogeneity, this component is more accurately determined through a CPMG pulse sequence and thus will be discussed in that section. However, the CPMG sequence used is not able to measure relaxation times on the microsecond scale, such as those associated with the $\mathrm{T}_{2 \mathrm{~s}}{ }^{*}$ component.

To quantify how much material changed from a solidlike to a liquid-like fraction, the ratio $\mathrm{I}_{2 \mathrm{~m}}{ }^{*} / \mathrm{I}_{2 \mathrm{~s}}{ }^{*}$ was calculated, where $\mathrm{I}_{2 \mathrm{~m}}{ }^{*}$ and $\mathrm{I}_{2 \mathrm{~s}}{ }^{*}$ are the total signal intensities associated with the $\mathrm{T}_{2 \mathrm{~m}}{ }^{*}$ and $\mathrm{T}_{2 \mathrm{~s}}{ }^{*}$ fractions, respectively (Figure 4). For comparison, moisture content determined by gravimetric measurement is also shown. For films with $0.3 \mathrm{~g}$ of glycerol/g SPI, there was no significant difference between the moisture content and $\mathrm{I}_{2 \mathrm{~m}}{ }^{*} / \mathrm{I}_{2 \mathrm{~s}}{ }^{*}$ over all $\mathrm{a}_{\mathrm{w}}$. With increasing glycerol content, 

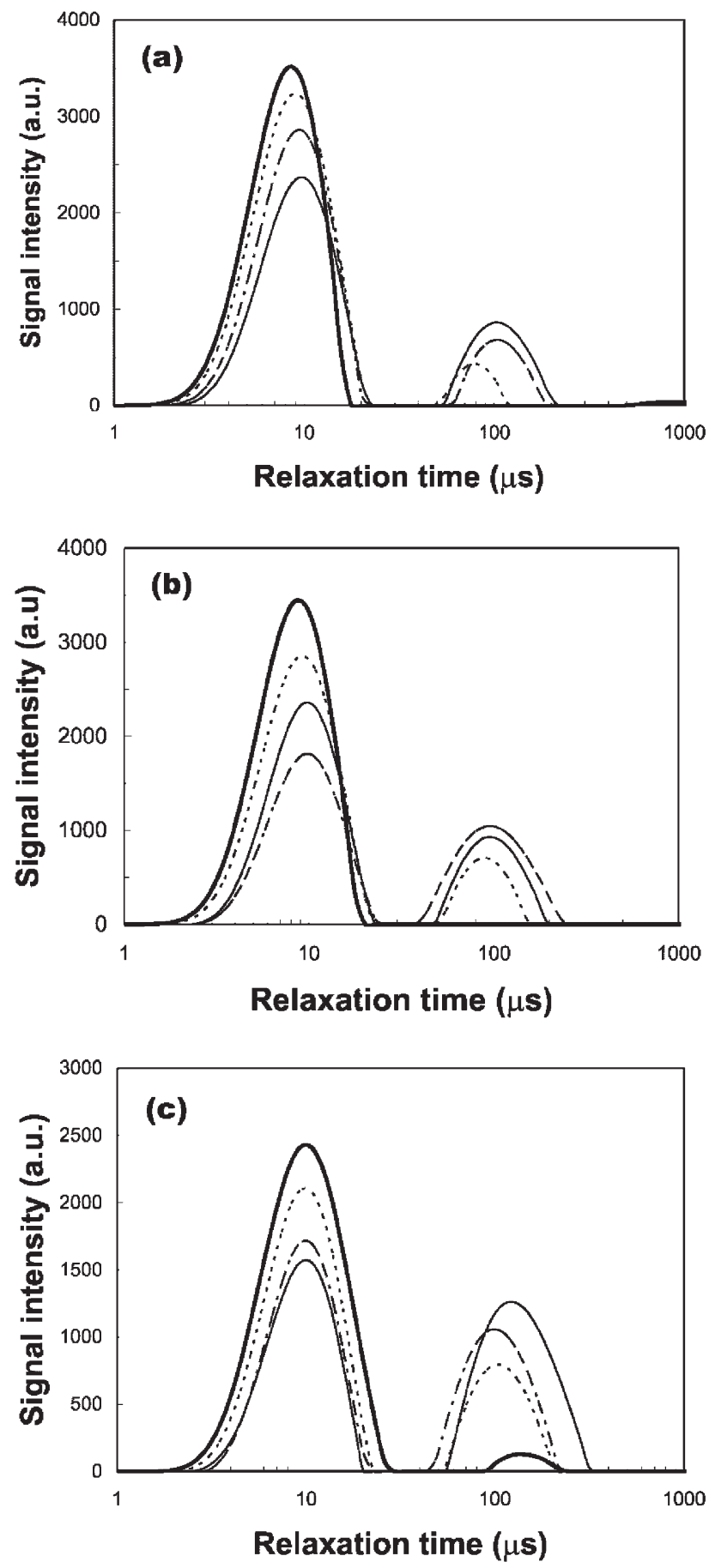

Figure 3. Distributed $T_{2}{ }^{*}$ relaxation times of soy-protein isolate (SPI) films at different $\mathrm{a}_{\mathrm{w}}$, as determined by single pulse sequence: (a) 0.3 $\mathrm{g}$ glycerol/g SPI, (b) $0.5 \mathrm{~g}$ glycerol/g SPI, and (c) $0.7 \mathrm{~g}$ glycerol/g SPI $\left(-=a_{\mathrm{w}}=0 ;-\cdots=\mathrm{a}_{\mathrm{w}}=0.23 ;-\cdot \cdot \cdot=\mathrm{a}_{\mathrm{w}}=0.53 ;-=\mathrm{a}_{\mathrm{w}}\right.$ $=0.81)$

$\mathrm{I}_{2 \mathrm{~m}}{ }^{*} / \mathrm{I}_{2 \mathrm{~s}}{ }^{*}$ was much higher than the water content in films as $a_{w}$ increased. This suggests that glycerol immobilized by the SPI network or otherwise displaying solid-like characteristics becomes part of the more mobile aqueous phase. Thus, water may affect the SPI-based films by plasticization for low glycerol-plasticized films (below $0.5 \mathrm{~g}$ glycerol/g SPI), and by both plasticization and solubilization for higher glycerol-plasticized films. Plasticizer and protein solubilization were ob-

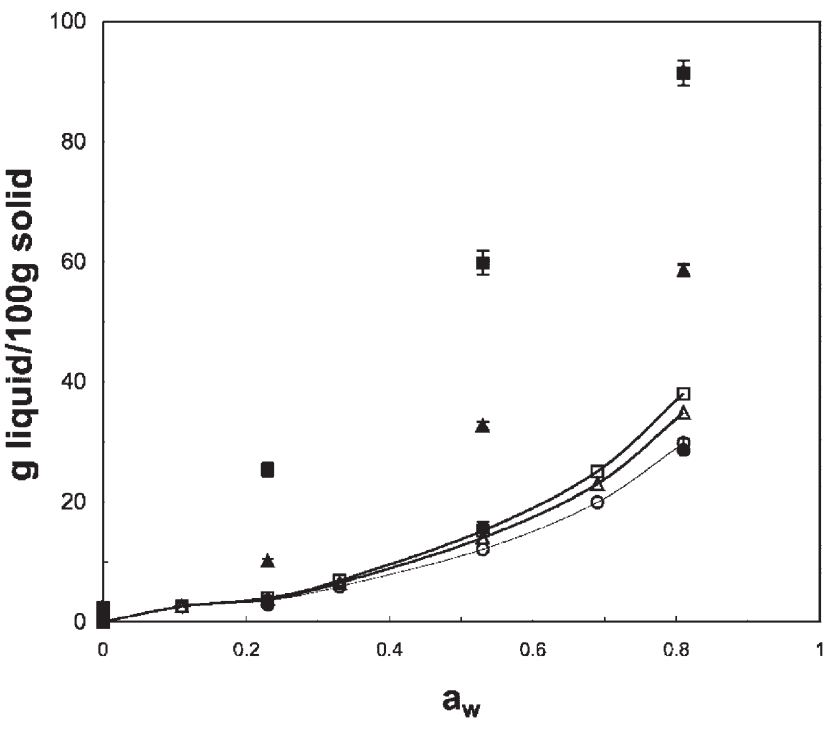

Figure 4. The ratio of liquid to solid fraction in films based on nuclear magnetic resonance (NMR) $\left(\mathrm{I}_{2 \mathrm{~m}}{ }^{*} / \mathrm{I}_{2 \mathrm{~s}}{ }^{*}\right)$ and gravimetric moisture content as a function of $\mathrm{a}_{\mathrm{w}} \cdot \mathrm{I}_{2 \mathrm{~m}}{ }^{*} / \mathrm{I}_{2 \mathrm{~s}}{ }^{*}$ ratio: $0=0.3 \mathrm{~g}$ glycerol $/ \mathrm{g}$ soy-protein isolate (SPI); $\boldsymbol{\Delta}=0.5 \mathrm{~g}$ glycerol/ $\mathrm{g}$ SPI; $\boldsymbol{\square}=0.7 \mathrm{~g}$ glycerol/g SPI. Moisture content: $\bigcirc=0.3 \mathrm{~g}$ glycerol $/ \mathrm{g}$ SPI; $\Delta=0.5 \mathrm{~g}$ glycerol/g SPI; $\square=0.7 \mathrm{~g}$ glycerol $/ \mathrm{g}$ SPI.

served for films based on wheat gluten, soy proteins, or crosslinked whey protein (Gontard and others 1992; Mahmoud and Savello 1993; Stuchell and Krochta 1994). Mahmoud and Savello (1993) and Stuchell and Krochta (1994) have pointed out that there is increased protein solubilization when hydrophilic plasticizer content increased in whey protein- based and soy protein-based films. They suggested that a decrease in the polymer network interaction density caused by the plasticizer was associated with this increase in solubility properties.

\section{Transverse relaxation from CPMG experiment}

To further investigate the relaxation behavior of the more mobile components, the transverse relaxation data were also obtained using the CPMG sequence. The CPMG sequence gives a more accurate measurement of transverse relaxation in more mobile components (Le Botlan and Helie-Fourel 1995; Tang and others 2000). The resulting curves were analyzed using a distributed exponential routine (Figures 5a-5c). For films with $0.3 \mathrm{~g}$ glycerol/g SPI, no signal was observed at $\mathrm{a}_{\mathrm{w}}=0$, whereas for films with $0.5 \mathrm{~g}$ and $0.7 \mathrm{~g}$ glycerol $/ \mathrm{g}$ SPI, a small and seemingly bimodal signal was observed. This is consistent with results from the single-pulse experiments, that is, at $0.3 \mathrm{~g}$ glycerol/g SPI and $a_{w}=0$, a relatively immobile fraction $\left(\mathrm{T}_{2}{ }^{*}\right.$ of approximately $10 \mu \mathrm{s}$ ) was observed, but the more mobile fraction $\left(\mathrm{T}_{2}{ }^{*}\right.$ of approximately $\left.100 \mu \mathrm{s}\right)$ was not. The CPMG results most likely correspond to the more mobile fraction of the single-pulse results. For example, at 0.7 g glycerol/g SPI, a signal in the $80-\mu$ s to $800-\mu$ s region was observed by CPMG, corresponding to the $T_{2 m}{ }^{*}$ signal that emerged in the single-pulse experiment in similar conditions.

From the CPMG measurements, only 1 population of spins was observed for all sample films over all $\mathrm{a}_{\mathrm{w}^{\prime}}$ within the region of 0.1 to $2 \mathrm{~ms}$. This suggests that more mobile glycerol and water molecules interact rapidly and are not hindered by diffusional barriers. As glycerol concentration increased, the relaxation time and signal intensity increased, indicating increased mobility and fraction of mobile protons in the films. 

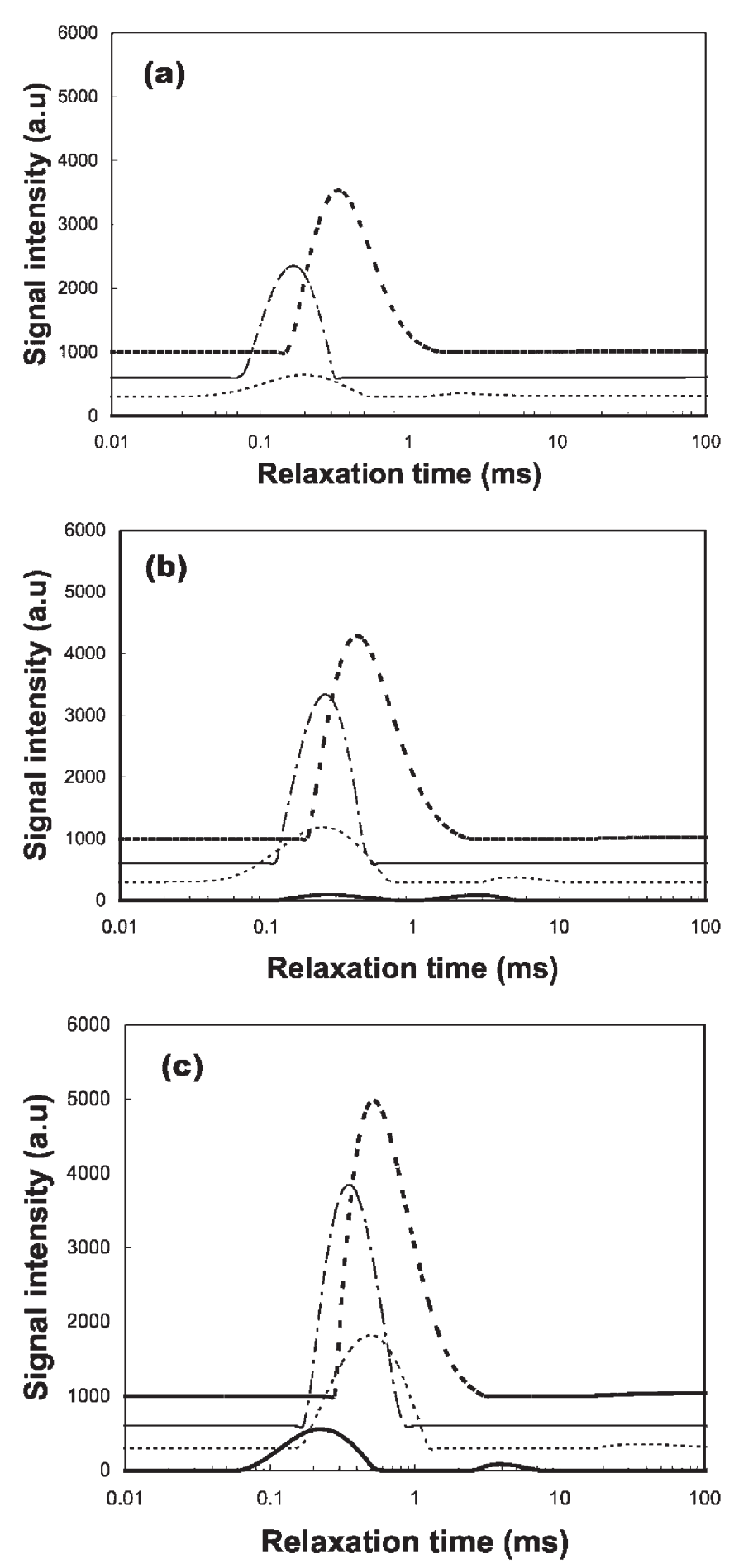

Figure 5. Distributed $\mathrm{T}_{2}$ relaxation times of soy-protein isolate (SPI) films at different $\mathrm{a}_{\mathrm{w}^{\prime}}$ as determined by Carr-Purcel-Meiboom-Gill (CPMG) pulse sequence: (a) 0.3 g glycerol $/ \mathrm{g}$ SPI; (b) 0.5 g glycerol $/ \mathrm{g}$ SPI; and (c) 0.7 g glycerol $/ \mathrm{g}$ SPI. $\left(-=\mathrm{a}_{\mathrm{w}}=0 ;---=\mathrm{a}_{\mathrm{w}}=0.23 ;-\right.$. $-\cdot \cdot=\mathrm{a}_{\mathrm{w}}=0.53$; $=\mathrm{a}_{\mathrm{w}}=0.81$ )

The exception is that at $0.7 \mathrm{~g}$ glycerol/ $\mathrm{g}$ SPI, a small secondary peak was observed at approximately 3 to $9 \mathrm{~ms}$. This suggests that there is more than 1 domain of glycerol molecules at this glycerol concentration. However, at higher moisture contents, diffusion is enhanced such that these molecules can rapidly diffuse.

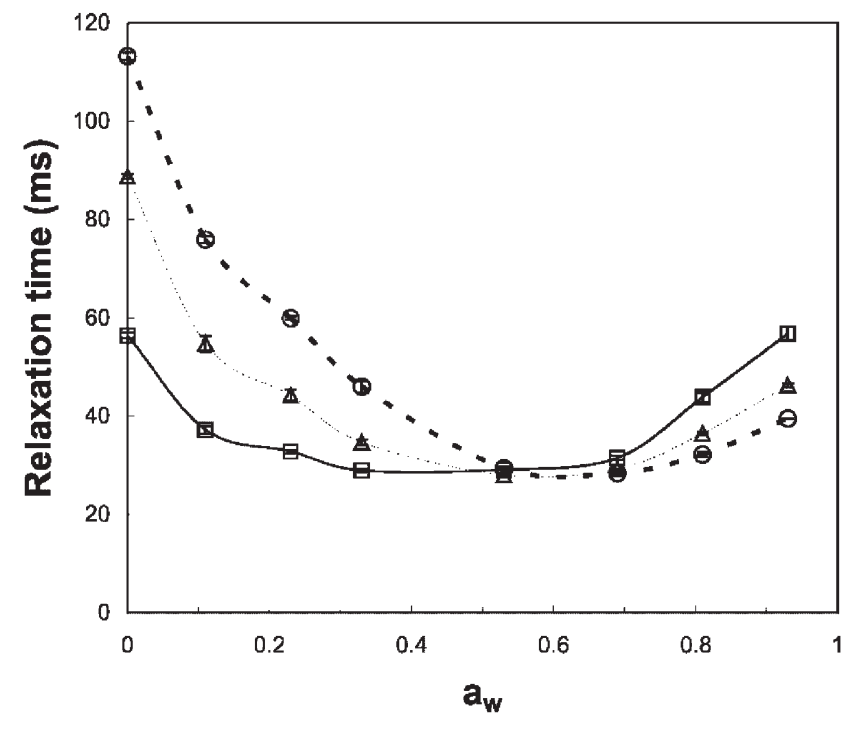

Figure 6. $\mathrm{T}_{1}$ relaxations for soy-protein isolate (SPI) films with different glycerol content as a function of aw $(\mathrm{O}=0.3 \mathrm{~g}$ glycerol $/ \mathrm{g}$ SPI; $\Delta=0.5 \mathrm{~g}$ glycerol $/ \mathrm{g}$ SPI; $\square=0.7 \mathrm{~g}$ glycerol $/ \mathrm{g} \mathrm{SPI})$.

\section{Longitudinal relaxation from inverse-recovery pulse experiment}

Longitudinal relaxation time $\left(\mathrm{T}_{1}\right)$ constants for SPI films, prepared with different glycerol contents and as a function of $\mathrm{a}_{\mathrm{w}}$, are shown in Figure $6 . \mathrm{T}_{1}$ relaxation reflects a combined effect of intermolecular spacing and intramolecular dipolar interaction. $\mathrm{T}_{1}$ relaxation is sensitive to the separation between nuclei and to the molecular structure (Hore 1995; Kim and Cornillon 2001). The longitudinal relaxation decay was found to be a single exponential for all film samples studied. All samples showed a distinct minimum $\mathrm{T}_{1}$ value, typical of low-moisture biopolymer systems such as starch, pectin, casein, and protein (Leung and others 1976; Shirley and Bryant 1982; Tanner and others 1991; Ratkovic and Pissis 1997; Kou and others 2000).

Ratkovic and Pissis (1997) suggested one interpretation of the $\mathrm{V}$-shaped curves obtained for $\mathrm{T}_{1}$ compared with water content in cereal and legume macromolecular systems. They found that water content at the minimum $\mathrm{T}_{1}$ corresponded to the primary hydration sphere (a monolayer) around the macromolecules and that the minimum $\mathrm{T}_{1}$ was dependent on chemical composition rather than resonance frequency. When the water content was further increased, $\mathrm{T}_{1}$ also increased due to plasticization of macromolecules, resulting in more motional freedom in the whole system. At $\mathrm{a}_{\mathrm{w}}$ below that associated with the minimum $\mathrm{T}_{1}$, the addition of water to the dried sample resulted in a decrease in the $\mathrm{T}_{1}$. This was attributed to cross-relaxation and spin exchange becoming the dominant phenomena at lower moisture levels. The proton spins of water molecules in a monolayer around protein molecules exchange with exchangeable protons on protein. Consequently, proton relaxation would be enhanced.

Tanner and others (1991), investigating the $\mathrm{T}_{1}$ of waxy maize starch containing $18 \% \mathrm{D}_{2} \mathrm{O}$, found no corresponding $\mathrm{T}_{1}$ minimum and indicated that the reduction in the relaxation times of the starch samples occurs primarily as a consequence of the water motion rather than through the mobility of starch. They suggested that mobility associated with both the wa- 
ter and starch may allow the hydrated polymer system to approach more closely the minimum- energy conformation.

In contrast, Kou and others (2000), investigating $\mathrm{T}_{1}$ relaxation of waxy cornstarch, suggested that the minimum $T_{1}$ may be useful as an indicator of a transition from the glassy to viscous rubbery state at a specific temperature. They found that moisture ranges of waxy cornstarch, having a minimum $\mathrm{T}_{1}$ relaxation, were consistent with moisture contents required for a glass transition at the specific temperature.

In our results, the increases in $\mathrm{T}_{1}$ at $\mathrm{a}_{\mathrm{w}}$ below that associated with the minimum $T_{1}$ were more pronounced with decreasing glycerol content in film formulation. This was expected as hydroxyl groups on glycerol can exchange protons with protein. This also indicates that glycerol may stabilize the film structure at low water levels. This interpretation is consistent with those suggested by Crowe (1971). He pointed out that substances containing hydroxyl groups such as glycerol, trehalose, or sugar alcohols can stabilize the structures of macromolecular or membrane surfaces in conditions of extreme dehydration.

The addition of plasticizer in the film formulation did affect the minimum $T_{1}$ over all $a_{w}$ ranges. The minimum $T_{1}$ of the films occurred at progressively lower $\mathrm{a}_{\mathrm{w}}$ with increasing glycerol content. For example, the minimum $\mathrm{T}_{1}$ values for the films, with glycerol concentration of $0.3 \mathrm{~g}, 0.5 \mathrm{~g}$, and $0.7 \mathrm{~g}$ based on $g$ SPI, were observed at $\mathrm{a}_{\mathrm{w}}$ of $0.69,0.53$, and 0.33 (corresponding to equilibrium moisture contents of $0.20 \mathrm{~g} \mathrm{H}_{2} \mathrm{O}$, $0.14 \mathrm{~g} \mathrm{H}_{2} \mathrm{O}$, and $0.07 \mathrm{~g} \mathrm{H}_{2} \mathrm{O}$, based on g solid), respectively. If, as suggested by Kou and others (2000), the minimum $T_{1}$ is indicative of a glass transition, our results indicate that films with more glycerol undergo a glass transition at lower moisture levels.

\section{The relationship between functional and NMR properties as affected by $a_{w}$ and plasticizer}

The influences of water and glycerol on the mechanical and barrier properties of edible films have been investigated widely (Gontard and others 1993; Lawton 1996; Lim and others 1999; Cho and Rhee 2002). Gontard and others (1993) reported that changes in puncture strength and elasticity were found to be a function of $\mathrm{a}_{\mathrm{w}}$. For instance, wheat gluten film at $30^{\circ} \mathrm{C}$ had maximum puncture strength at $\mathrm{a}_{\mathrm{w}}$ between 0.7 and 0.8 . In addition, sharp increase in water vapor transmission and film extensibility occurred at these levels of $a_{w}$. They postulated this was due to 2 types of water. During hydration of gluten film, the first water fraction (from $0 \mathrm{~g}$ to $5 \mathrm{~g} / 100 \mathrm{~g}$ dry matter) is adsorbed and improves film elasticity and puncture resistance, probably caused by the formation of supplementary hydrogen bonds between protein chains. The second water fraction $(>15 \mathrm{~g} / 100 \mathrm{~g}$ dry matter) reduces the strength required to break the protein chain bonds, and the gluten film changes from an elastic to viscous material. Similar observation on the starch-based films was observed by Lawton (1996). He found that the films had a maximum tear-resistant value at intermediate moisture levels. Gontard and others (1993) also emphasized that maximum puncture resistance of the gluten films occurred at a progressively lower $\mathrm{a}_{\mathrm{w}}$ as the temperature was increased. Ferry (1980) reported that dependence of ultimate mechanical properties (rupture stress and strain) on temperature was similar to that of viscoelastic properties. An increase in free volume to the films by increasing temperature may shift to lower $\mathrm{a}_{\mathrm{w}^{\prime}}$ at which maximum puncture resistance occurred. Gontard and Ring (1996) reported that a glass transition in gluten films was highly correlated to the sharp changes in the film properties in response to moisture content and/or temperature.
Cho and Rhee (2002) reported that tensile strength (TS) of SPI films reflected a combined effect of glycerol and water in plasticizing films. For instance, the films with lower glycerol content had higher TS values; films with $0.3 \mathrm{~g}, 0.5 \mathrm{~g}$, and $0.7 \mathrm{~g}$ of glycerol/g SPI had a TS of 32 to $4 \mathrm{MPa}, 24$ to $2 \mathrm{MPa}$, and 14 to $1 \mathrm{MPa}$, respectively, at $\mathrm{a}_{\mathrm{w}}$ ranges between 0.11 and 0.75 . In addition, the TS for films prepared with lower glycerol contents were more sensitive to RH conditions compared with the higher glycerol samples; the TS for films with $0.3 \mathrm{~g}$ of glycerol/g SPI progressively decreased over all $\mathrm{a}_{\mathrm{w}}$ ranges, whereas those for films with $0.5 \mathrm{~g}$ and $0.7 \mathrm{~g}$ of glycerol/g SPI sharply decreased up to $\mathrm{a}_{\mathrm{w}}$ of 0.43 and 0.23 , respectively, and above these $\mathrm{a}_{\mathrm{w}}$ ranges, decreases in TS were small. They also found that the minimum $\mathrm{RH}$ condition, which is required for imparting flexibility to the films, decreased with increasing plasticizer concentration.

Our results suggest that the molecular dynamics of films are dependent on plasticizer concentration and $\mathrm{a}_{\mathrm{w}}$. These may be related to mechanical or functional properties of films in similar conditions as observed by others. For example, we observed a minimum $\mathrm{T}_{1}$ at similar $\mathrm{a}_{\mathrm{w}}$ that Gontard and others (1993) have found maximum puncture resistance, greatest increase in film flexibility, and water vapor properties. This result supports studies by Kou and others (2000) and Gontard and Ring (1996), who suggested that minimum $\mathrm{T}_{1}$ relaxation and glass transitions occurred at a similar moisture content, at a specific temperature, and that maximum puncture strength and sharp changes in film properties was associated with a glass transition.

The $\mathrm{a}_{\mathrm{w}}$ corresponding to a minimum $\mathrm{T}_{1}$ decreased with increasing glycerol content. Cho and Rhee (2002) found similar results for flexibility of SPI films. That is, as glycerol levels were increased, the $\mathrm{a}_{\mathrm{w}}$ at which films became flexible occurred at lower values. This may be explained in terms of an increase in free volume to the films with increasing glycerol content, leading to decrease in water content that is required for a glass transition. Consequently, it is suggested that the measurement of $\mathrm{T}_{1}$ relaxation can be used to predict the film properties that are related to a glass transition.

In addition, $\mathrm{T}_{2 \mathrm{~s}}{ }^{*}$ depended on both glycerol and $\mathrm{RH}$; the peak $\mathrm{T}_{2 \mathrm{~s}}{ }^{*}$ of lower glycerol films gradually decreased over all $\mathrm{a}_{\mathrm{w}^{\prime}}$ but those of higher glycerol films were less sensitive to $\mathrm{a}_{\mathrm{w}}$ variation. This trend is similar to that for tensile strength reported by Cho and Rhee (2002). This indicates that the mobility of solid-like component in films may be related to tensile strength of the films. As $a_{w}$ increased, the changes of solid-like fraction to liquid-like fraction was more observed in higher glycerol films. This may be related to the solubilization of protein and glycerol by water. This is similar to the solubility behavior of films in water reported by several researchers (Gontard and others 1992; Mahmoud and Savello 1993; Stuchell and Krochta 1994).

\section{Conclusions}

The molecular dynamics of SPI-based films were found to be altered by plasticizer and $a_{w}$. The distributed transverse relaxation of films identified 2 distinct components: a solidlike fraction $\left(\mathrm{T}_{2 \mathrm{~s}}{ }^{*}\right)$ and a liquid-like fraction $\left(\mathrm{T}_{2 \mathrm{~m}}{ }^{*}\right)$. The peak $\mathrm{T}_{2 \mathrm{~s}}{ }^{*}$ values of films with lower glycerol concentration were more sensitive to variation in $\mathrm{a}_{\mathrm{w}}$ compared with the higher glycerol samples. This indicated that the solid-like fraction is more plasticized by water. As $a_{w}$ increased, the change of solid-like fraction to liquid-like fraction was observed in films 
prepared with higher glycerol content. This may be related to the solubilization of soluble protein and glycerol by water. All film samples had a minimum $\mathrm{T}_{1}$ relaxation as a function of $\mathrm{a}_{\mathrm{w}}$. As glycerol content increased, the $\mathrm{T}_{1}$ minimum shifted to lower $a_{w}$. It is of interest that we observed a minimum $T_{1}$ in the films at the same conditions others have measured a glass transition and a sharp change in mechanical properties. These results suggest that molecular dynamics of films is highly associated with the mechanical or functional properties of films and that the studies on molecular mobility of films may help to characterize the roles of plasticizer and water in the formulation of the edible films.

\section{References}

Banker GS. 1966. Film coating theory and practice. J Pharm Sci 55:81-9.

Barbot J, Gueguen J, Popineau Y. 2003. Molecular determinants of the influence of hydrophilic plasticizers on the mechanical properties of cast wheat gluten films. J Agric Food Chem 51(5):1447-52.

Cherian G, Gennadios A, Weller C, Chinachoti P. 1995. Thermomechanical behavior of wheat gluten films: Effect of sucrose, glycerin, and sorbitol. Cereal Chem 72:1-6.

Cho SY, Rhee C. 2002. Sorption characteristics of soy protein films and their relation to mechanical properties. Lebensm-Wiss Technol 35:151-7.

Choi SG, Kerr WL. 2003. ${ }^{1} \mathrm{H}$ NMR studies of molecular mobility in wheat starch. Food Res Int 36:341-8.

Crowe JH. 1971. Anhydrobiosis-unsolved problem. Am Nat 105:563.

Cuq B, Gontard N, Guilbert S. 1995. Edible films and coatings as active layers. In: Rooney ML, editor. Active food packagings. Glasgow: Blackie Academic and Professional. p 111-42.

De Leiris JP. 1985. Water activity and permeability. In: Mathlouthi $\mathrm{M}$, editor. Food packaging and preservation: Theories and practice. New York: Elsevier Applied Science Publishers. p 213.

Ferry JD. 1980. Ultimate mechanical properties. In: Ferry JD, editor. Viscoelastic properties of polymers. New York: Wiley. p 583-7.

Gennadios A, Park HJ, Weller CL. 1993. Relative humidity and temperature effects on tensile strength of edible protein and cellulose ether films. Trans ASAE 36:1867-72.

Gennadios A, Weller CL. 1994. Moisture adsorption by grain protein films. Trans ASAE 37:535-9.

Gontard N, Guilbert S. 1994. Bio-packaging: Technology and properties of edible and/or biodegradable material of agricultural origin. In: Mathlouthi M, editor. Food packaging and preservation. Glasgow: Blackie Academic and Professional. p 159-81.

Gontard D, Guibert S, Cuq JL. 1992. Edible wheat gluten films: Influence of the main process variables on film properties using response surface methodology. J Food Sci 57:190-5.

Gontard N, Guilbert S, Cuq J. 1993. Water and glycerol as plasticizers affect mechanical and water vapor barrier properties of an edible wheat gluten film. J Food Sci 58:206-11.

Gontard N, Ring S. 1996. Edible wheat gluten film: Influence of water content on glass transition temperature. J Agric Food Chem 44:3474-8.

Hore PJ. 1995. Nuclear magnetic resonance. New York: Oxford Univ. Press.

Kester JJ, Fennema O. 1986. Edible films and coating: A review. Food Technol (Chicago) 40:47-59.

Kim YR, Cornillon P. 2001. Effects of temperature and mixing time on molecular mobility in wheat dough. Lebensm-Wiss Technol 34:417-23.
Kou Y, Dickinson LC, Chinachoti P. 2000. Mobility characterization of waxy corn starch using wide-line ${ }^{1} \mathrm{H}$ nuclear magnetic resonance. J Agric Food Chem 48:5489-95.

Krochta JM, Baldwin EA, Nisperos-Carriedo M. 1994. Edible films and coatings to improve food quality. Lancaster, Pa.: Technomic Publishing.

Lawton JW. 1996. Effects of starch type on the properties of starch containing films. Carbohydr Polym 29:203-8.

Le Botlan D, Helie-Forel I. 1995. Assessment of the intermediate phase in milk fat by low-resolution nuclear magnetic resonance. Anal Chim Acta 311:217- 23.

Leung HK, Steinberg MP, Wei LS, Nelson AI. 1976. Water binding of macromolecules determined by pulsed NMR. J Food Sci 41:297-300.

Lim LT, Mine Y, Tung MA. 1999. Barrier and tensile properties of transglutaminase cross-linked gelatin films as affected by relative humidity, temperature, and glycerol content. J Food Sci 64:616-22.

Mahmoud R, Savello PA. 1992. Mechanical properties of and water vapor transferability through whey protein films. J Dairy Sci 75:942-6.

Mahmoud R, Savello PA. 1993. Solubility and hydrolyzability of films produced by transglutaminase catalytic crosslinking of whey protein. J Dairy Sci 76:29- 35.

McHugh TH, Krochta JM. 1994. Sorbitol- vs glycerol-plasticized whey protein edible films: integrated oxygen permeability and tensile property evaluation. J Agric Food Chem 42:841-45.

Meiboom S, Gill D. 1958. Modified spin-echo method for measuring nuclear relaxation times. Rev Sci Instrum 29:688-91.

Monahan FJ, O'Riordan ED, O'Sullivan M. 2002. Physical properties of WPI films plasticized with glycerol, xylitol, and sorbitol. J Food Sci 67(1):164-7.

Morillon V, Debeaufort F, Capelle M, Blond G, Voilley A. 2000. Influence of the physical state of water on the barrier properties of hydrophilic and hydrophobic films. J Agric Food Chem 48:11-6.

Park HJ, Bunn JM, Weller CL, Vergano PJ, Testin RF. 1994. Water vapor permeability and mechanical properties of grain proteinbased films as affected by mixtures of polyethylene glycol and glycerin plasticizers. Trans ASAE 37:1281-5.

Provencher SW. 1982. A constrained regulation method for inverting data represented by linear algebraic or integral equations. Comp Phys Comm 27:213- 27.

Ratkovic S, Pissis P. 1997. Water binding to biopolymers in different cereals and legumes: Proton NMR relaxation, dielectric and water imbibition studies. J Mater Sci 32:3061-8.

Shirley WM, Bryant RG. 1982. Proton-nuclear spin relaxation and molecular dynamics in the lysozyme-water system. J Am Chem Soc 104:2910-8.

Stading M, Hermansson AM. 2000. Relationship between the microstructure and the mechanical and barrier properties of whey protein films. J Agric Food Chem 48(9):3806-16.

Stuchell YM, Krochta JM. 1994. Enzymatic treatment and thermal effects on edible soy protein films. J Food Sci 59:1332-7.

Tang HR, Godward J, Hills B. 2000. The distribution of water in native starch granules-A multinuclear NMR study. Carbohydr Polym 43:375-87.

Tanner SF, Hills BP, Parker R. 1991. Interactions of sorbed water with starch studied using proton nuclear magnetic resonance spectroscopy. J Chem Soc Faraday T 87:2613-21.

Vittadini E, Dickinson LC, Chinachoti P. 2001. ${ }^{1} \mathrm{H}$ and ${ }^{2} \mathrm{H}$ NMR mobility in cellulose. Carbohyd Polym 46:49-57. 